\title{
The role of the YMCA in shaping modern sport and the Olympic Movement in Germany
}

\author{
Tomáš Tlustý* \\ Faculty of Education, University of South Bohemia in České Budějovice, České Budějovíce, Czech Republic
}

Copyright: (C) 2018 T. Tlustý. This is an open access article licensed under the Creative Commons Attribution License (http://creativecommons.org/licenses/by/4.0/).

\begin{abstract}
Background: This paper looks at the history of physical education and sport in the German Young Men's Christian Association (YMCA). Objective: The aim of this article is to show the contribution of the YMCA to the formation of modern sports and the Olympic movement in Germany. Methods: Standard historical methods are used therein. Everything is written in chronological order. Results: The first local German YMCA was established in 1883. It gradually began to assume responsibility for much of the physical education sphere in Germany, although sport had clearly not yet become a prominent part of German physical education. That did not change until the 1920's, when the German YMCA teamed up with other Protestant groups to form the Reichsverband der Evangelischen Jungmännerbünde Deutschlands (the German Reich Association of Protestant Young Men). Physical education and sport were organized through its Eichenkreuz division but that was banned in 1934. After being restored in 1947, the Eichenkreuz division again began to shape physical education in Germany, which the YMCA still does today. Conclusions: The article shows that even though the YMCA in Germany did not have an influence on formation of sports and the Olympic movement comparable to the one in the neighboring Czechoslovakia and Poland, it undoubtedly became known for German inhabitants in this field. That means it should not be omitted from the history of physical education and sport in Germany.
\end{abstract}

Keywords: Eichenkreuz, CVJM, physical education and sport, history, protestant groups

\section{Introduction}

Modern sport started to be formed at the turn of the $18^{\text {th }}$ and the $19^{\text {th }}$ century. Before that games and the entertainment (the predecessor of sport) were refused by radical Protestants as something inappropriate that diverts people from their duties and proper life. The relief of the situation came up later. International sport unions and the modern Olympic movement started to develop at the turn of the $19^{\text {th }}$ and the $20^{\text {th }}$ century. From this time the interest in sport grew even among Protestants.

The YMCA (Young Men's Christian Association) primarily aims to bring young Christians together. However, its initial religious framework was rapidly extended to cover teaching and physical education (Riess, 1923).

The YMCA was established in London in 1844 by George Williams, a draper's assistant. It started out with only twelve members and it aimed to offer young

\footnotetext{
* Address for correspondence: Tomáš Tlustý, Department of Sport Studies, Faculty of Education, University of South Bohemia in České Budějovice, Na Sádkách 2/1, 37005 České Budějovíce, Czech Republic. E-mail: tomtlusty@pf.jcu.cz
}

people the chance to spend their free time in line with Christian principles.

Initially, a small group of enthusiasts joined the YMCA. However, as the association extended its program, it soon gained popularity. In turn, the YMCA's ideas began to spread quickly, not only within the United Kingdom.

The greatest development of the YMCA was achieved in the USA, where the English sport system was gradually taken over and modernized. The first founders of organized sport here were especially Protestants, some of whom were even members of the YMCA (e.g. Luther Halsey Gulick).

In 1851, the first two offices were established on the American continent, in Montreal and Boston (Zawisza, 1930). The American YMCA then set about modernizing the association's program as a whole. It began to strongly prioritize physical education and sport and spread these new ideas into South America, Asia and, following the end of the First World War, back into Europe as well (Johnson, 1979).

Meanwhile, the YMCA was paving its own way in Europe. In 1852, George Williams spent time in 
Paris on business. He met with local pastors, offering them financial support to establish a YMCA office in Paris. From there, the YMCA spread into the Netherlands (1853), Hungary (1883) and Germany (1883; Konečný, 1930).

The aim of this work is to bring a brief but apt view on the formation of the YMCA organization in Germany, especially in the field of physical education and sport from the beginning through the $21^{\text {st }}$ century.

\section{Methods}

Standard historical methods are used in the article. Particular events should be mentioned chronologically as they happened.

Concerning the fact that the article is focused on quite a wide timescale and large area, only the events of the highest importance will be mentioned.

Many historical as well as more current titles, written in many languages, especially German, were used as sources. Unfortunately, in most of the used materials, only minimum information about this topic can be found. The reason is that the most of it discusses the American YMCA. Probably the best sources of information on this topic are the Eichenkreuz Mitteilungen journal and texts of R. Müller.

The search for resources was performed in one of the biggest physical education libraries in Germany - in the University of Cologne library. Keywords YMCA, CVJM and Eichenkreuz were mostly used for the searching. Because the article deals also with the relationship of the YMCA and the Olympic movement, the Carl und Liselott Diem-Archiv funds were also searched. Unfortunately, almost no information about the YMCA was found there.

\section{The beginnings of the German YMCA}

The first local YMCA office was opened in Germany in the 1880's. However, the German national association currently reports that the beginnings of the German YMCA date back to 1823 (Schröder, 2012), which is 21 years before the London YMCA had been established by George Williams. The YMCA had apparently followed up on the newly formed young men's society, the Mission-Jünglingsverei, which Carl Wilhelm Isenberg had established in the same year in the town of Barmen (In 1929, the towns of Barmen, Elberfeld, Vohwinkel, Ronsdorf, Cronenberg, Langerfeld and Beyenburg merged to form the city of Wuppertal.), aged just sixteen (Brandenburg, 1993).
As time went on, other Protestant youth associations began to appear in Germany, such as the Rheinisch-Westfälische Jünglingsbund (the Rhenish-Westfalian Youth Association), which was established in Elberfeld in 1848 ("CVJM-Geschichte", n.d.). In 1882, the Teutoburg Forest became the venue for the first rally of five German youth associations ("125 Jahre CVJMGesamtverband”, 2007) which laid the foundation for the German YMCA.

The first local YMCA was established in Berlin, an achievement attributed to Friedrich von Schlümbach, a German-American Protestant. It was here that Eberhard von Rothkirch (Hahn-Bruckart, 2011) became the first ever chairman. The German YMCA was renamed several times in its history. It was not until 1985 that the name was settled as Christliche Verein Junger Menschen (CVJM), which is a translation of the English original ("125 Jahre CVJM Berlin”, 2008).

The YMCA soon began to expand its activity into other German towns. Munich became host to the second local office in turn to be established in Germany in 1886.

The YMCA's Nuremberg office dates back to 1890, when Otto Erhard established a young man's club in Gostenhof. Three years later, military chaplain Friedrich Eichler made efforts to establish a YMCA office. The office was supposed to operate as a refuge for young soldiers far from home. These two branches officially merged to become the Nuremberg YMCA on $23^{\text {rd }}$ October 1898, Friedrich Eichler being placed in charge of the local office.

Here, the YMCA immediately began to bring men of all ages together. However, members were separated into groups of children, teenagers, young adults and seniors for its activities, which were held in all kinds of places around the city. Premises to house the local office were finally built in 1908 (“CVJM-Geschichte”, n.d.).

\section{The beginnings of physical education and sport in the German YMCA}

As in many other countries around the world, physical education and sport were an inseparable part of the German YMCA's program. It has been very hard to trace the real origin of the first sports groups formed by the above-mentioned predecessors of the German YMCA. However, it can be assumed that physical education mainly found its place in German Protestant youth associations, which were established during the $19^{\text {th }}$ century in western Germany and merging in 1848 to form the above-mentioned Rheinisch-Westfälische Jünglingsbund (the Rhenish-Westfalian Youth Association; Schnabel, 1993). 
Naturally, the real origin of physical education and sport in the German YMCA date back even further. In 1893 (Müller, 1991) the first gymnasium was opened by the still relatively new local YMCA in Berlin. This gymnasium was located on Wilhelmstraße (Müller, 1988a). However, most German youth associations of the time were geared towards the Deutsche Turnerschaft (the German Gymnastics Association), the German nationalist organization established in 1868. This organization significantly contributed to Germany's victory over France in 1870. At that time, German physical education had quite a strong military character (Kössl, Štumbauer, \& Waic, 2004).

Newly emerging youth associations began to take over most of Germany's established physical education sphere, though, the YMCA being one of the youth associations that did not become too involved in political matters in Germany.

Unlike local YMCAs in the United States of America, the German YMCAs probably did not dedicate much of their physical education sphere to sport. They were more likely to focus on physical exercise including exercises of a military character. The Berlin YMCA's first sports club was mainly focused on members who wanted to prepare for carrying out military service (Niemeier, 1923).

However, it was not long before the two approaches to physical education clashed. The American YMCA entered Europe during the First World War and began to promote its own approach to physical education.

\section{American YMCA activity in Germany during the First World War}

1914 saw the outbreak of the First World War. It was triggered by the successful attempt to assassinate Franz Ferdinand of Austria, the Habsburg Archduke of Austria-Este and successor to the throne. This precipitated the Austro-Hungarian Empire's declaration of war against Serbia, causing a chain reaction that led to First World War. Within one month, almost the whole of Europe found itself mobilised to wage war.

Members of the World Alliance of YMCAs quickly reacted to the situation that had arisen. On $4^{\text {th }}$ August 1914, they met for the first time in London, arranging another two councils that were to be held by the end of August 1914. It was in London that the YMCA established its voluntary war work policy. Geneva, Switzerland, became home to the Council of Voluntary War Work (Tlustý, 2017).

An act of great significance came on $12^{\text {th }}$ August 1914 when all members of the World Alliance were sent letters from the Swiss headquarters urging for help in
European battlefields. The International Committee of the YMCAs of North America in New York also received a telegraph from Switzerland, asking the American Association to send financial support and qualified secretaries to help with YMCA war work in Europe.

Funding from the YMCA World Alliance had not been particularly high as Great Britain waged war with Germany and neither the British nor the German National Council was willing to donate money to the World Alliance to cover war expenses. Members of the National Councils of YMCAs in Great Britain and Germany were already taking care of their own military troops to a great extent, anyway (Hopkins, 1979).

Despite the United States of America being a neutral country, the American YMCA was eager to get involved in the military campaign. But how could they do that whilst preserving the United States of America's neutrality? The only way was to help people on both sides of the conflict. John R. Mott arranged with the General Secretaries of the English and German National Councils for American YMCA workers to be given the opportunity to enter local prisoner-of-war camps (Steuer, 1998a).

In February 1915 the USA's Archibald Clinton Harte visited the German metropolis of Berlin. He arrived with a proposal to get YMCA volunteers working in prisoner-of-war camps without hesitation (Hoffman, 1915). The Prussian Minister of Defence gave permission to have aid and support sent for prisonersof-war, but he was in no mind to give his consent to all of A. C. Harte's requests. YMCA service was to be introduced into as many prisoner-of-war camps as possible and the number really was large.

Members of the American YMCA had no chance of covering such a large number of prisoner-of-war camps by themselves. By the end of 1915 there were still only two of their secretaries in Germany, so the German National YMCA Council and other local associations had to be contacted with requests for help (Steuer, 1998a).

Soon after A. Harte had managed to get YMCA war work approved in Germany, the first two camps were chosen to get the whole effort under way. The first YMCA war hut $(30 \times 90$ feet $)$ was opened on $15^{\text {th }}$ April 1915, situated near the town of Göttingen in Lower Saxony. It consisted of a large hall, reading room, small hall and three classrooms (Bartholomew, 1915). At first, visiting the hut was free of charge but later a membership fee of 15 pfennigs a month was introduced (Steuer, 1998a). Work soon began in other prisoner-of-war camps, with YMCA huts beginning to appear in them. There were often sports going on next to the huts, as there were usually sports grounds for basketball, volleyball, football and baseball. There were 
even tennis courts in the Hannover-Münden prisonerof-war camp or areas for boxing (Bartholomew, 1915).

As soon as the United States of America entered the war, Germany insisted on expelling all American workers from all of its prisoner-of-war camps. Despite having spent the previous three years working actively with prisoners from a wide variety of armed forces, costing them a great deal of money, the American YMCA became perceived by the general public as a great benefit to the U.S. Armed Forces (Taft, Kent, Newlin, \& Harris, 1922b). Its sole chance of replacing American secretaries in Germany was to call up YMCA secretaries from neutral countries. Sports equipment continued to be sent to prisoner-of-war camps, where the wide variety of matches, tournaments and leagues were not greatly hindered (Steuer, 1998b). In addition, there were now Americans among the prisoners-of-war in Germany, which provided another chance for the American YMCA (Steuer, 1998b).

In November 1918, almost a week after the truce, the Americans began to march east from France into Germany. They were joined by the YMCA, which went on to closely cooperate with the American army in Germany (Taft et al., 1922b).

During the First World War, the American YMCA sent Europe a total of almost 760 tonnes of sports material worth more than 1.5 million American dollars. Most of this material was directed to France but Germany did not do badly either (Taft et al., 1922a).

\section{A brief history of physical education and sport in the German YMCA after the First World War}

YMCA activity in Germany was greatly paralyzed by the First World War. It was not a complete disaster for them, though. The early 1920s saw growth of the YMCA in Germany, also bringing great change to the association's physical education and sports program. Leisure activities and trips grew in popularity, attracting thousands of young people ("CVJM-Geschichte", n.d.). There was a gradual move away from traditional physical exercise. At the $10^{\text {th }}$ annual National Conference of German YMCAs, held in Kassel in 1921, an agreement was made to combine physical exercises with sport in the physical education sphere in all local associations (Müller, 1996a).

In the same year, representatives of each local YMCA met representatives of the Jungmännervereine (German Young Men's Association) and agreed on forming a new united association - Reichsverband der Evangelischen Jungmännerbünde Deutschlands (the German Reich Association of Protestant Young Men), which was to organize part of the program content (including physical education and sport) on a nationwide level (Boberach, Nicolaisen, \& Pabst, 2010).

The Eichenkreuz (Oak Cross) physical education and sports division was also established by the association in 1921. This was an important step towards making physical education and sport more accessible to German Protestant organizations. At that time, members of the YMCA and other Protestant associations that had been incorporated into it wore a badge carrying its symbol - an oak cross - on their uniform. The Eichenkreuz division soon began to recruit employees who dedicated themselves to its program on a full-time basis (Müller, 1996b).

Establishing the physical education division, Eichenkreuz, incorporating the German YMCA into it, publishing its magazine and holding sporting galas in western and southern Germany were the first important steps to be taken by the YMCA to develop physical education and sport in Germany. There is, however, still uncertainty today as to the extent physical education and sport was included in association activity and the role played by this element of their program. In Germany, sporting members were not separated in any way from members who were involved in other parts of the YMCA program either.

However, one significant change arose in 1923, by which time they had begun to regularly participate in sports competitions, not wearing the red triangle badge (the YMCA symbol) though, but the oak cross.

Alcohol was very often a topic of concern. As, for example, in Czechoslovakia, the YMCA in Germany took the same stance against the use of alcohol, which it claimed contradicted healthy human development. Other topics of concern included finding an appropriate place for physical exercise (indoor or outdoor spaces), the benefits of sports spectatorship and including football in the Eichenkreuz division's program.

However, at that time, the Eichenkreuz division did not greatly contribute to the overall development of physical education and sport in Germany. During this era neither Catholic nor Jewish sport clubs and organizations played a significant part in the development of the physical education and sport in Germany.

The most popular sports included faustball (Faustball or Fistball - a ball hit over a net with the fist. This is one of the oldest known sports of all. The earliest known written mention is by Roman Emperor Gordian III and dates to the year 240 A.D. The first rules were recorded by Antonius Scaiono in 1555. In the late $19^{\text {th }}$ century, George Heinrich Weber drafted the first modern rules in Germany, where the first regular tournaments began to be played in 1893 and are still played on a large scale today.) and, naturally, football. In 1922 a request was made to merge the Eichenkreuz 
division with the Reichsausschuss für Leibesübungen (the German Reich Committee for Physical Exercise). There was a simple reason for that - the idea of getting the Protestant division involved in the Deutsche Kampfspiele (the German Fighting Games), held in 1922, 1926, 1930 and 1934 (The YMCA probably did not establish many relationships with other organizations that focused on physical education and sport at first. The obvious exception was the competing at different sports events.). These games, aiming to express the power of German unity and the physical strength and proficiency of young Germans, were indeed highly nationalist and militarist in nature.

Having received permission to take part, it was important for the associations to be represented by true Christian figures. Although it is not absolutely clear why the Eichenkreuz division was so eager to take part in the German Fighting Games, there are a number of theories. They may have wanted to have the Eichenkreuz division acknowledged within German sport, made attempts to assess the work they had carried out in the field of physical education and sport or been attracted by the possibility to take part in various training courses and the right to participate in events organized by the German Reich Committee for Physical Exercise (Müller, 1988a).

Membership by no means meant provision of financial support, though. Physical education and sport leaders of the Eichenkreuz division did not feel at all in a position to interfere in the development of sport in Germany, which was a very different approach from their counterparts in the neighbouring countries of Czechoslovakia and Poland (Bureš \& Plichta, 1931).

Physical education functionaries strived to lead their trainees through simple exercises, which they did not need any equipment for, which had straightforward rules and for which they preferred free movement in the fresh air. Members were then divided into several groups according to performance (Müller, 1988a).

It can be said that the birth of the Eichenkreuz Gymnastics Festival goes back to this time, first held in Nuremberg in 1927 (Ueberhorst, 1985). Mass marches, which had become firmly rooted at the time, were a typical feature of the Festival. Nevertheless, efforts were also made to include all-round sport (athletics, hiking, skiing, sailing and, from 1930, basketball). Recreation by the sea and in the mountains was also offered on a large scale.

Thoughts on the structure of the Eichenkreuz division were again deepened in 1932 after Ewald Hartmann published his book called Der Christ und der Sport. The book was the first major attempt to link sport and Christian values and to include it in biblical theological thought and action. This created a new direction for sport, which began to distance itself from national physical education thinking (Hartmann, 1932).

In 1930, Berlin hosted the first sports congress for European National YMCAs, where basketball was presented and later added to the Eichenkreuz division program.

By taking on new physical education challenges, becoming more open to the public and being a member of the German Reich Committee for Physical Exercise, the association grew in terms of membership numbers. However, rising membership numbers led to the need to intensify all activity, both regionally and centrally.

In 1931, the Eichenkreuz division celebrated its tenth anniversary. At that time, the whole division was misunderstood by the public in two ways:

1. People thought that sport in the Eichenkreuz division was something specifically Christian because of the Eichenkreuz conviction to nurture Christian sport.

2. The Eichenkreuz is a way of inducing young people to join the YMCA.

In May 1931, the Eichenkreuz published its declaration Leibesübungen im Lichte der evangelischen Weltanschauung (Physical Education in the Light of Protestant Values), which attempted to clarify any misunderstandings (Müller, 1988a). Its main objective was to provide an all-round education regarding the body and its balanced physical development in line with its soul and spirit. This ideology corresponded with the YMCA's triangle, which symbolizes these three perspectives (Schroeder, 1925).

Despite preferring all-round physical education, they did actually include traditional notions such as athletics or team games. However, their sporting activity remained competitive only on an inter-member basis or just for fun and no championships were arranged. Their aim was by no means to produce top sportsmen.

The unemployed were often called on to assist in running these leisure activities, which could also have involved erecting the necessary facilities or camps. In return, they were given food and lodging.

In the years to follow, the ideology of building and expanding a young and strong nation strengthened in the minds of Eichenkreuz members and the division's activities. More and more exercises of a military nature were required to be included in the club's various ceremonies: military parades, terrain exercises and gun firing.

The Eichenkreuz division's days became numbered in 1933, when German young men's physical education gradually began to unify. Moreover, the 
National Socialists began to suppress Christian sporting movements.

In April 1933, the newly appointed Reichssportkommissar (German Reich Sports Commissioner) set out to unify all physical education associations. The German Reich Committee for Physical Exercise was dissolved (Diner, Reuveni, \& Weiss, 2012) and the Deutschen Reichsbund für Leibesübungen (the National Socialist Reich Association for Physical Exercise) was set up. Together with the Hitler Youth, it began to place great demands on the organization of sport in Germany. Young men under the age of 18 with a desire to do sport had no other option than to join the Hitler Youth (Gruner, 2008).

Hence, even the various Protestant young men's associations were forced to join their ranks. Needless to say, such actions provoked a wave of opposition from the various associations that had imminently been forced to incorporate. The Eichenkreuz spoke out against the ruling, arguing that Protestant youth associations could not restrict themselves to religious activity. This soon led to the club's downfall and it was banned in 1934, not to reappear for a lengthy period of time (Müller, 1988a).

However, the YMCA yet again stepped in to shape German sport prior to the Second World War, on the very important occasion of the XI Olympic Games held in 1936 in Berlin.

Due to constant human rights violations in Germany, the American Olympic Committee decided to boycott these Olympic Games. However, the German government was extremely interested in American participation. Knowing that the American YMCA had the power to influence the American Olympic Committee, it asked the German YMCA to appeal to their American counterparts to call off the boycott and have the American team participate in the Olympic Games. The German government had seemingly acceded to the demand to allow Jews to take part and did everything it could to come across as a good host. Propaganda efforts promoted the friendly atmosphere and peaceable hospitality of the German nation. The YMCA was subsequently allowed to erect its tent in the Olympic grounds and it was given permission to organize its own mass sporting event (Müller, 1986).

In the end, the boycott was called off by the American Olympic Committee and the US sent a team to the Berlin Olympics. Following the Games, however, it surfaced that the world had been misled by German propaganda, and the country continued to persecute the Jews and mobilize. These facts would later go on to influence the German YMCA's 1980 decision to firmly oppose German participation in the XXII Olympic Games in Moscow (Müller, 1988b).

\section{Physical education in the German YMCA from 1945 to present day}

The Eichenkreuz division was reestablished in the German town of Willingen in 1947, under the auspices of E. Stange. A new set of rules was introduced.

In 1951, the Eichenkreuz became a member of the newly established Deutscher Sportbund (the German Sports Federation). Two years later, the first German Eichenkreuz Championships were held to mark the European YMCA Conference. In 1955, the German Volleyball Federation was established, an achievement attributed to John Zeigert, the German YMCA's Sports Secretary at the time. Regular Deutsche Eichenkreuzmeisterschaften (the German Eichenkreuz Federation Championships) have been held since 1965 and from then on German YMCA teams have also regularly participated in the YMCA European Championships. In 1984, the first German YMCA Games (CVJM-Spiele) took place in Kassel, with a turnout of over 2,800 sportsmen. In 2005, a sports festival was held in Kassel to mark the $150^{\text {th }}$ anniversary of the YMCA becoming an international organization (in Paris in 1855; Waic \& Köss1, 1992). Since 2006, the German YMCA ceased to organize sport within the Eichenkreuz division and began to call its physical education division "CVJMSport" ("Zahlen und Fakten”, n.d.).

\section{Conclusions}

In Germany, the first local YMCA office was opened in 1883, when, in a certain way, the organization followed up on the activity of established Protestant associations. To begin with, the German YMCA's physical education and sports program was partly inspired by local trends. Being more focused on physical exercise, the German program was very different from that in the United States of America. However, the two differing approaches merged during the First World War.

After the First World War, the German YMCA teamed up with other Protestant organizations to form the German Reich Association of Protestant Young Men. Responsibility for physical education and sport was entrusted to its Eichenkreuz division, which, as time went on, began to put a greater emphasis on sport.

In 1934, the Eichenkreuz division was dissolved and its members were forced to join the Hitler Youth if they wanted to continue attending physical education and sport activities. The Eichenkreuz division was restored in 1947, when it was completely re-established and operated until 2006. This year the German YMCA ceased to organize sport within the Eichenkreuz 
division and began to call its physical education division "CVJM-Sport".

The German YMCA is currently made up of thirteen independent local associations. Its headquarters aims to promote mutual cooperation, arrange common activities and to gain support and raise awareness of their needs within the government, institutions, Church and general public. In addition, German YMCA leaders strive to arrange various conferences, interviews and meetings both for members and the general public and to report on its activity via printed and electronic media ("YMCA Germany", n.d.).

\section{Conflict of interest}

There were no conflicts of interest.

\section{References}

125 Jahre CVJM Berlin: Jubiläum bei Deutschlands ältesten „CVJM“ [125 years of YMCA Berlin: Anniversary of Germany's oldest "YMCA"]. (2008). CVJM-Informationen, 2008(2), 18.

125 Jahre CVJM-Gesamtverband: Jubiläumsfeier in Detmold [125 years of the YMCA general association: Anniversary celebration in Detmold]. (2007). CVJM-Informationen, 2007(6), 4.

Bartholomew, M. M. (1915). A visit to prison camps. In J. Mott (Ed.), For the millions of men now under arms (Number 5) (pp. 44-45). New York, NY: Association Press.

Boberach, H., Nicolaisen, C., \& Pabst, R. (2010). Handbuch der deutschen evangelischen Kirchen, 1918 bis 1949 (Organe - Ämter - Verbände - Personen, Band 1: Überregionale Einrichtungen) [Handbook of the German protestant churches, 1918 to 1949 (Institutions - Offices Associations - People, Volume 1: Supraregional bodies)]. Göttingen, Germany: Vandenhoeck \& Ruprecht.

Brandenburg, H. (1993). Die Anfänge evangelischer Jugendbewegung (Der Weg der Schülerbibelkränzchen von 1883 bis 1919) [The beginnings of the protestant youth movement (The way of the student bible studies from 1883 to 1919)]. Pulheim, Germany: Rheinland-Verlag.

Bureš, P., \& Plichta, J. (1931). Sport a tělesná kultura v Čsl. republice a cizine [Sport and the physical culture in Czechoslovakia and abroad]. Prague, Czechoslovac Republic: Almanach sportu.

CVJM-Geschichte [CVJM - History]. (n.d.). Retrieved from https://www.cvjm-nuernberg.de/ueber-uns/geschichte \#1844

Diner, D., Reuveni, G., \& Weiss, Y. (2012). Deutsche Zeiten (Geschichte und Lebenswelt. Festschrift zur Emeritierung von Moshe Zimmermann) [German papers (History and present. Commemorative to the retirement of Moshe Zimmermann)]. Innenstadt, Germany: Vandenhoeck \& Ruprecht.

Gruner, W. (2008). Die Verfolgung und Ermordung der europäischen Juden durch das nationalsozialistische
Deutschland 1933-1945 (Deutsches Reich 1933-1937) [The persecution and murder of European Jews by national socialist Germany 1933-1945 (German Reich 19331937)]. Munich, Germany: Oldenbourg.

Hahn-Bruckart, T. (2011). Friedrich von Schlümbach Erweckungsprediger zwischen Deutschland und Amerika (Interkulturalität und Transkonfessionalität im 19. Jahrhundert) [Friedrich von Schlümbach - Awakening preacher between Germany and America (interculturality and transconfessionalism in the $19^{\text {th }}$ century)]. Göttingen, Germany: Vandenhoeck \& Ruprecht.

Hartmann, E. (1932). Der Christ und der Sport [The Christian and the sport]. Munich, Germany: Verlag P. Müller.

Hlaváč, P. (2010). YMCA v Československé armádě na začátku 20. stol. [YMCA in Czechoslovak army at the beginning of the $20^{\text {th }}$ century]. In J. V. Hynek (Ed.), YMCA v proměnách času (pp. 5-8). Prague, Czech Republic: YMCA in Czech Republic.

Hoffman, C. (1915). Impression of a secretary. In J. Mott (Ed.), For the millions of men now under arms (Number 5) (p. 43). New York, NY: Association Press.

Hopkins, C. H. (1979). John R. Mott (1865-1955, A biography). Grand Rapids, MI: William B. Eerdmans Publishing Company.

Johnson, E. L. (1979). The history of YMCA physical education. Chicago, IL: Association Press.

Konečný, J. (1930). YMCA: její vznik, dějiny a význam [YMCA: Its origin, history and importance]. Prague, Czechoslovak Republic: Československá akciová tiskárna.

Kössl, J., Štumbauer, J., \& Waic, M. (2004). Vybrané kapitoly $z$ dějin tělesné kultury [Chosen chapters from the history of the physical culture]. Prague, Czech Republic: Karolinum.

Müller, R. (1986). Die Olympischen Spiele 1936 - und was der CVJM damit zutun hatte [The Olympic Games 1936 - and what the CVJM had to do with it]. Eichenkreuz Mitteilungen, 1986(5), 1-3.

Müller, R. (1988a). Der Versuch einer Interpretation der Geschichte der Eichenkreuz-Sportarbeit im CVJM [An attempt to interpret the history of the Eichenkreuz sports work in the CVJM]. In R. Müller (Ed.), Kasseler Hefte, S21 (Eichenkreuz Sport im CVJM) (pp. 4-22). Kassel, Germany: CVJM.

Müller, R. (1988b). Der CVJM bei den Olympischen Spielen [The CVJM at the Olympic Games]. Eichenkreuz Mitteilungen, 1988(4), 12.

Müller, R (1991). 100 Jahre Basketball [100 years of basketball]. Eichenkreuz Mitteilungen, 1991(6), 4.

Müller, R. (1996a). Eichenkreuz Wird 75 Jahre [Eichenkreuz will celebrate 75 years]. Eichenkreuz Mitteilungen, 1996(3), 1.

Müller, R. (1996b). Von 60 Jahren [60 years]. Eichenkreuz Mitteilungen, 1996(3), 2.

Niemeier, G. (1923). Vom Säegang und Sichelklang im Westdeutschen Jünglingsbund [Of the Säegang and Sichelklang in the West German Youth Federation]. Barmen, Germany: Westdt. Jünglingsbund.

Riess, L. W. (1923). Úkoly tělovýchovného odboru Ymky

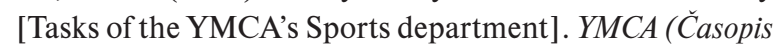
sdružení YMCA v Československu), 2(3), 65-68.

Schnabel, W. (1993). Die evangelische Posaunenchorarbeit (Herkunft und Auftrag) [The protestant church choir work 
(origin and order)]. Göttingen, Germany: Vandenhoeck \& Ruprecht.

Schroeder, L. C. (1925). Historie tělesné výchovy YMCA [The history of the YMCA's physical education]. YMCA (Časopis sdružení YMCA v Československu), 4(1), 7-9.

Schröder, B. (2012). Religionspädagogik [Religious education]. Tübingen, Germany: Mohr Siebeck.

Steuer, K. A. (1998a). Pursuit of an "Unparalleled Opportunity": The American Y.M.C.A. and Prisoner-of-War Diplomacy among the Central Power nations during World War I, 1914-1923, (Volume 1) (Dissertation thesis). University of Minnesota, St. Paul, MN.

Steuer, K. A. (1998b). Pursuit of an "Unparalleled Opportunity": The American Y.M.C.A. and Prisoner-of-War Diplomacy among the Central Power nations during World War I, 1914-1923, (Volume 2) (Dissertation thesis). University of Minnesota, St. Paul, MN.

Taft, W., Kent, F., Newlin, W., \& Harris, F. (1922a). Service with fighting men (An account of the work of the American YMCA in the World War I), Volume I. New York, NY: Association Press.

Taft, W., Kent, F., Newlin, W., \& Harris, F. (1922b). Service with fighting men (An account of the Work of the American
YMCA in the World War I), Volume II. New York, NY: Association Press.

Tlustý, T. (2017). Budování národních organizací YMCA v Československu a Polsku: Rozvoj tělesné kultury v letech 1918-1939 [National YMCA groups in Czechoslovakia and Poland: Successful development of physical culture during the period from 1918 to 1939]. Prague, Czech Republic: Karolinum.

Ueberhorst, H. (1985). Wattenscheid: die Freiheit verloren? (Eine Sozialgeschichte) [Wattenscheid: Lost the freedom? (A social story)]. Dusseldorf, Germany: Droste.

Waic, M., \& Kössl, J. (1992). Český tramping 1918-1945 [Czech tramping 1918-1945]. Prague, Czech Republic: Práh.

YMCA Germany. (n.d.). Retrieved from http://www.cvjm. de/index.php?id=5713

Zawisza, W. (1930). Y.M.C.A. jako ruch wszechświatowy i Polska Y.M.C.A. [Y.M.C.A. as a universal movement and the Polish Y.M.C.A.]. Warsaw, Poland: Polska YMCA.

Zahlen und Fakten [Facts and figures]. (n.d.). Retrieved from https://cvjm.de/arbeitsbereiche/cvjm-arbeit-in-deutschland/ sport/ueber-cvjm-sport/zahlen-und-fakten/ 